\title{
Quaternary chronostratigraphy and the establishment of related standards
}

This paper represents a contribution by the Italian Commission on Stratigraphy to the ongoing discussion on the establishment of chronostratigraphic standards in the Quaternary.

We will argue that the Quaternary, in general, is no exception when discussing the principles and procedures for the establishment of chronostratigraphic standards.

The consolidated approach to use (open) marine sediments outcropping onland to harbour the golden-spike for the base of chronostratigraphic units is to be upheld even in the Quaternary. Plenty of significant sections are present, among other places, in Southern Italy, which has always been recognised as the type-area for the marine Quaternary since the early nineteenth century.

We will also review the present situation of official or semi-official chronostratigraphic units and boundaries in the Quaternary with a view at contributing pragmatically to establish the best way forward for the ICS Subcommission on Quaternary Stratigraphy in the next few years.

\section{Introduction}

After a period of inactivity that followed the last attempt to lower the Pliocene-Pleistocene boundary (see further on), the Subcommission on Quaternary Stratigraphy (SQS) was requested by its parent organisation (the International Commission on Stratigraphy, ICS) to undertake a thorough review of its membership and policies and a very pragmatic effort towards the establishment of the Quaternary Standard Chronostratigraphic Scale. It is in this context that this position paper was first conceived. Therefore, it represents a sort of open letter to the new officers of SQS to help them focus in the best way on some key-issues that pave the way toward the establishment of standards for the internal subdivisions of the Quaternary. A commitment undertaken by ICS with the International Union of Geological Sciences (IUGS), in fact, binds us to complete the Standard Chronostratigraphic Scale by 2008.

After an appeal not to waste priceless efforts on the PliocenePleistocene boundary issue, we will try to: a) expose our philosophical approach to the chronostratigraphic subdivision of the Quaternary; b) describe the present status of Quaternary Chronostratigraphy; and c) give our suggestions on the future objectives, work programme and membership of the new SQS.

\section{An appeal on the Pliocene-Pleistocene boundary issue \\ Before presenting our views on the approach to be upheld in the chronostratigraphic subdivisions of the Quaternary, a brief excursus is in order on the never-ending debate on the Pliocene-Pleistocene boundary. \\ The writers of this paper firmly believe in the validity and appropriateness of the choice that led the stratigraphic community to}

first select (1985) and then confirm (1999) the Vrica boundary as base of the Pleistocene (and of the Quaternary).

In our opinion, that boundary perfectly respects the historical usage of the last two centuries, the binding resolution of the 1948 IGC in London, and the need for an easily correlatable boundary.

We briefly recall here below how the scientific community arrived at the selection of the Vrica Boundary.

\begin{abstract}
Following a decade of study and discussions by the International Union for Quaternary Research (INQUA) Subcommission la on Stratigraphy (Pliocene/Pleistocene Boundary) and International Geological Correlation Program Project 41 (Neogene/Quaternary Boundary), a draft proposal on the choice of a boundary stratotype for the Pliocene/Pleistocene boundary was submitted and approved by the INQUA Commission on Stratigraphy (acting as the Subcommission on Quaternary Stratigraphy of ICS) at the 1982 Moscow INQUA Congress. The Vrica boundary was selected among two other possible choices, one younger (around the Brunhes/Matuyama boundary) and one older (around the Gauss/Matuyama boundary). A formal proposal was subsequently submitted to and approved by the ICS in 1983 and published two years later (Aguirre and Pasini, 1985) together with the announcement (Bassett, 1985) that the content of the proposal had been formally ratified by the IUGS Executive as GSSP of the Pleistocene. Thus, the GSSP of the Pleistocene (and the Quaternary) was placed at the base of a claystone unit conformably overlying the sapropelic bed " $e$ " in the Vrica section in Calabria (Southern Italy).
\end{abstract}

Quite a large number of Quaternary scientists, mainly experts of different kinds of continental sediments and particularly active within INQUA, are convinced that changing the base of the Pleistocene (and the Quaternary) to make it coincide with the Gelasian Stage (now Upper Pliocene), would both improve its correlation potential and more accurately reflect the most important step in the onset of the so-called northern hemisphere glaciations. Their claim finally resulted in a postal ballot within the Subcommission on Neogene Stratigraphy (SNS) and SQS on the proposal to lower the base of the Pleistocene in the aforementioned sense. The proposal was rejected by a strict majority of votes.

Some of the opponents of the Vrica boundary have recently proposed to decouple the term Quaternary from the term Pleistocene. The Quaternary would then be a Sub-System, with its base coinciding with the base of the Gelasian Stage, which would then encompass two entire Series (Pleistocene and Holocene) and one Stage (the Gelasian) of a third Series (the Pliocene). This solution, however, would not only meet with our opposition on scientific grounds, but would also violate the nested hierarchy of the Standard Chronostratigraphic Scale and, therefore, is too complicated even to be proposed.

In any case, should this proposal ever be brought forward, it would have to follow the complete approval process of all chronostratigraphic units (SQS, then ICS and, finally, IUGS). In addition, we remark that this procedure can only be initiated 10 years after the

\footnotetext{
* E. Abbate, G. Cassinis, D. Castradori, R. Catalano, M. B. Cita, M. A. Conti, S. Cresta, M. Gaetani, L. Pampaloni, G. Orombelli, M. Parotto,

G. Pavia, I. Premoli Silva, D. Rio, L. Simone, R. Sprovieri, G. B. Vai.

Corresponding author: Davide Castradori, Eni/Agip, via Emilia 1, 20097 San Donato Milanese, Italy

Tel: +39-02-52063731; Fax: +39-02-52063844; E-mail: davide.castradori@ agip.it
} 
reconfirmation of the Vrica Boundary (i.e. in 2009; see guidelines by Remane et al., 1996).

Having said that, we ask the new SQS to officially undertake not to devote priceless efforts in the discussion on the Plio-Pleistocene boundary, bringing us all farther from, instead of nearer to, our main goal, i.e. the subdivision of the Quaternary in lower rank chronostratigraphic units.

We suggest keeping the lobbying activity, directed to a new attempt to change the base of the Quaternary (in any case following the rules of modern normative stratigraphy), firmly outside SQS doors, at least for the time being.

\section{Our philosophical approach to Quaternary Chronostratigraphy}

As defined at present, the Quaternary covers the last $1.8 \mathrm{Ma}$ of the Earth history.

At first sight, therefore, one could be tempted to believe that such a short and recent time span must necessarily be treated in a different way with respect to older periods. Moreover, one would probably expect that totally different range of time-resolution and degree of accuracy can be reached in dating endeavours in the Quaternary.

Finally, one could probably imagine that only marginal-marine, low-thickness, areal-limited marine sediments are available for stratigraphic studies of the Quaternary onland (Figures 1,2).

We maintain that, while such beliefs may somehow be acceptable in respect of the Holocene and uppermost Pleistocene, they are, however, certainly misleading when looking at the Quaternary in general. To demonstrate, in a single example, the basis of this last statement, we draw the readerís attention to the marine Quaternary, and the underlying Pliocene, in southern Italy.
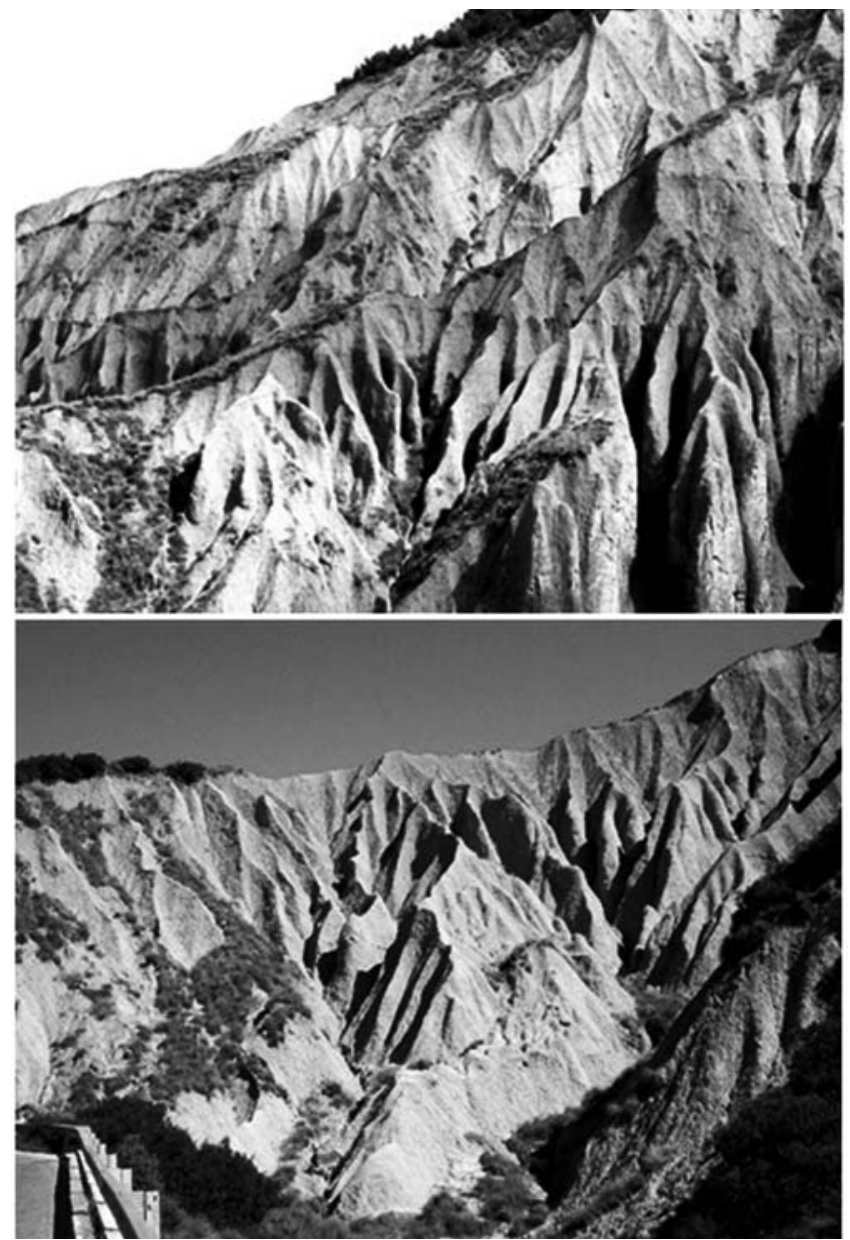

Figure 1 Montalbano lonico (Southern Italy): an excellent, open marine, lower to middle Pleistocene section.
A thorough review of two centuries of studies on the PlioPleistocene of southern Italy is, of course, far beyond the scope of this short paper. We then prefer to go straight to the conclusions that clearly demonstrate that:

- the Quaternary is represented, in large areas of southern Italy, by numerous excellent marine sections (as an example, see figure 1 depicting the Montalbano Ionico Section) representing the lower Pleistocene (up to 1000 metres), middle Pleistocene (hundreds of metres), and the lower part of the upper Pleistocene (tens of metres). They are testified by several stages and substages suggested in the last two centuries, some of which have been largely used and/or are still used (Calabrian, Santernian, Emilian, Sicilian, Selinuntian, Crotonian, Ionian, Tyrrhenian, Tarentian, Monastirian, Versilian) (Vai, 1996, 1997; Castradori \& Cita, 1995);

- marine sediments suitable for conventional biostratigraphy, magnetostratigraphy and marine isotope stratigraphy are present up to a time level as young as $2-300 \mathrm{ka}$, as testified by the beautiful sections of the Crotone Basin (see Figure 2a and 2b);

- for time intervals older than the limit of applicability of ${ }^{14} \mathrm{C}$ techniques, the time-resolution and degree of accuracy that one can reach in the Quaternary marine sediments are exactly the same as those, for example, of the underlying Pliocene and Miocene, i.e. those dictated by current orbital solutions applied to astrocyclostratigraphy (a few kyrs). For stratigraphic intervals older than the lower Miocene, direct astronomical dating, though no longer physically connected to the present day (via layer-by-layer
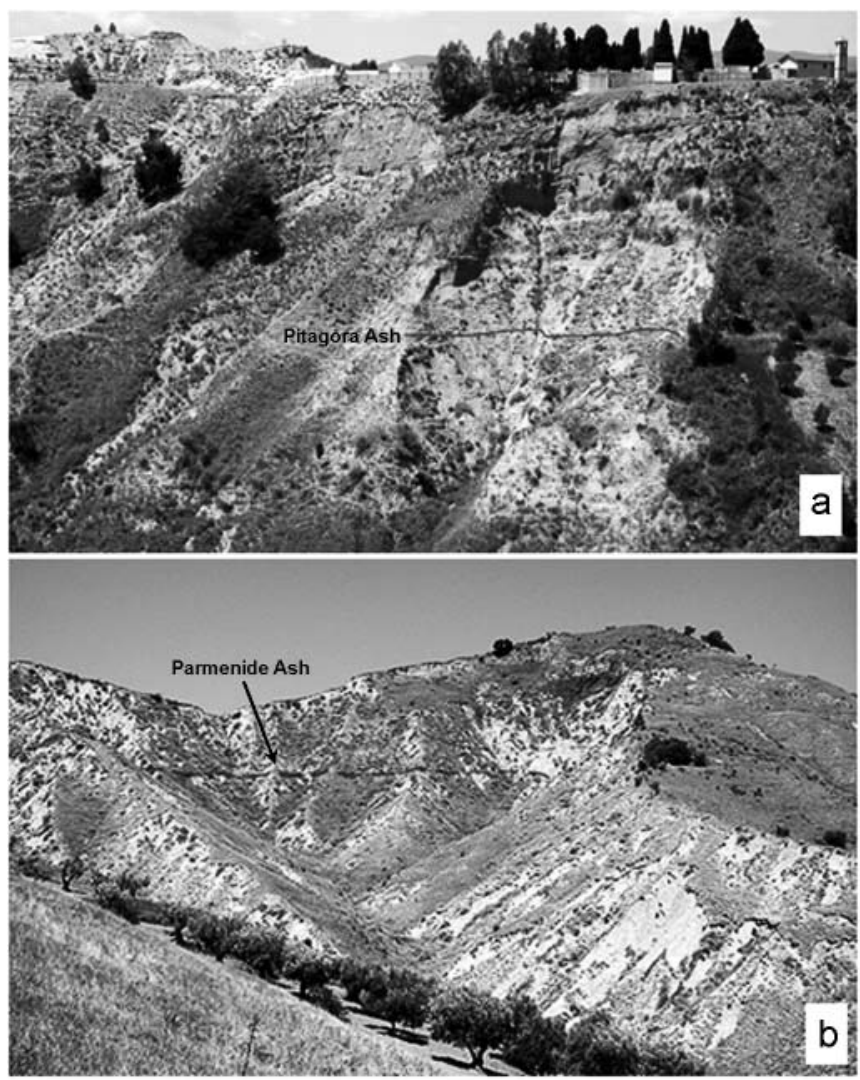

Figure 2 Middle Pleistocene sediments in the Crotone Basin (Calabria).

a) The "Valle di Manche" segment of the cyclically organized San Mauro succession. The onset of the Brunhes Chron has been confidently identified in outer shelf sediments containing an ash layer and representing the maximum flooding associated with MIS 19.

b) The middle-upper part of the Marcedusa succession, where outer shelf sediments correlated to MIS 11 have been recognized. A basinal correlatable ash layer is present at the MIS 12-MIS 11 transition. Both successions contain abundant pollens that allow comparison of continental and marine climatic conditions during the middle Pleistocene in Central Mediterranean. 
reconstruction of an ideally continuous composite section), nevertheless allow often for Milankovitch-like accuracy in time resolution.

It is incorrect to believe that the above considerations are only relevant to southern Italy. They are, on the contrary, valid worldwide, with particular reference to many other, tectonically active regions (Boso Peninsula in Japan, New Zealand and California, only to cite the most famous among many others).

In addition, marine sediment are obviously widespread and of various thickness under the world ocean floor. These last sediments are the field of study for so many scientific disciplines, as one can easily realise when examining a volume of the Ocean Drilling Program (see for example Leg 155, Amazon Fan, Legs 160 and 161, Mediterranean Sea), and should therefore be taken in the highest consideration when discussing how and where to set up standards of Quaternary chronostratigraphy.

In conclusion, we firmly believe that the Quaternary, as a whole, does not deserve any special treatment regarding to the definition of its standards.

As a result, the guide-lines for defining chronostratigraphic units (cfr. Hedberg, ed., 1976; Salvador, ed., 1994; Remane et al., 1996) by:

a) fixing the boundary-stratotype of their lower boundary,

b) following the principles of "base defines boundary",

c) fixing the boundary stratotypes in marine sediments,

d) respecting the historical usage (albeit not a true historical priority), and

e) focusing as much as possible on the best correlation potential, are all principles that should be firmly upheld even when talking about Quaternary chronostratigraphic standards.

This does not imply at all that we give continental sediments secondary importance in stratigraphy. We are fully aware of the great quantity and the excellent quality of the work that is being done on the Quaternary in different kinds of continental sediments and ice records, with particular reference to the reconstruction of the global climate changes. It would be enough to examine the portentous scientific production reported in journals like Paleo3, Quaternary International or Global Climate Change to get a flavour of these valuable efforts.

Framing these continental sediments within the chronostratigraphic standards defined in accordance with the aforementioned procedures, and establishing an auxiliary stratotype for those boundaries in continental sediments, will be the most challenging and interesting tasks.

We simply maintain that standards are to be fixed where the book is more complete (in marine sediments) and the assignment of fragments of story (the continental sediments) to one chapter or the other should logically follow as a second step.

Exceptions to this procedure can be proposed and discussed for the uppermost part of the Pleistocene and the Holocene for which the availability of onland marine sections suitable for integrated marine stratigraphy remains doubtful.

\section{Notes on the present status of Quaternary Chronostratigraphy}

Once again, it is not the scope of the present paper to overview the situation of chronostratigraphic units used in the Quaternary. A very detailed analytical treatise can be found in Vai (1996) and a short summary in Vai (1997).

Here, we only point out what is the situation of "official" chronostratigraphic units and boundary in the Quaternary to assess where we are now, and from where we are starting our research.

The only GSSP existing in the Pleistocene is the one defining its base in the Vrica Section (Calabria, Italy). This GSSP was ratified in 1985 (Aguirre and Pasini, 1985; Bassett, 1985) and confirmed by ICS in 1999 after a postal ballot within SNS and SQS (details on this last topic are found in Rio et al., 1998).

All the others subdivisions of the Pleistocene should be regarded as informal. This simply means that no official subdivision into units has ever been agreed upon by ICS, though the literature is rich with informal schemes that often enjoy wide acceptance.
With respect to this status of widespread informality, there are only two noteworthy exceptions: (a) the Calabrian Stage and (b) the Lower/Middle Pleistocene boundary.

(a) The Calabrian Stage is considered by some as already defined by the Vrica GSSP (e.g. Van Couvering, 1996; Vai, 1997), in agreement with a literal interpretation of the famous resolution adopted by the IGC in London (1948), in which the Pliocene/Pleistocene boundary was to be tied to the base of the Calabrian Stage. Others workers (see Rio et al., 1991 and references therein), on the contrary, argued that the base of most sections indicated by Gignoux (1913) as a reference for the Calabrian (albeit not true type-sections in a classical sense) was in fact younger than the base of the supposedly overlying Sicilian Stage which, in addition, enjoyed historical "priority" (Doderlein, 1872). More precisely, the "type-sections" of the Calabrian Stage would actually be of middle Pleistocene age, in case the lower/middle Pleistocene boundary is taken at about the level of isotope stage 22 or 24 (see below). This would render unacceptable the use of the Calabrian, though redefined by the GSSP of its base, as the type of the lower Pleistocene. As a result, the Calabrian Stage, according to those authors, had to be abandoned. A different situation would exist in case of definition of the lower/middle Pleistocene at the Brunhes-Matuyama boundary (see below). In this case, the "type-section" of the Calabrian Stage would at least be of (latest) early Pleistocene age. Therefore, the use of the term Calabrian could more easily be salvaged, though the "historical priority" of the Sicilian would still remain an issue.

In conclusion, the Calabrian Stage could be or not be regarded as a formally defined unit of the lower Pleistocene, according to different stratigraphic schools. This is one of the issues the new SQS will have to face soon.

(b) Also the lower/middle Pleistocene boundary enjoys an almost official status. In fact, according to Richmond (1996), the Brunhes-Matuyama paleomagnetic boundary was selected as primary criterion for the selection of the lower/middle Pleistocene boundary by the INQUA Commission on Stratigraphy, acting as Subcommission on Quaternary Stratigraphy of ICS. No boundary stratotype was proposed in that paper, even if its importance was acknowledged and the search for a suitable section apparently initiated. The truth is that no formal proposal in the direction indicated by Richmond (1996) has ever reached the point of being put to vote within the SQS and the status of the lower/middle Pleistocene boundary remained, and still remains, unofficial.

Other workers (see Cita and Castradori, 1995) proposed a lower interval (between the top of the Jaramillo event and the BrunhesMatuyama boundary), and the related events (e.g. base of the Pseudoemiliania lacunosa Nannofossil Zone), as more suitable for the selection of the lower/middle Pleistocene boundary, based also on evidence from the mammalian record. However, this proposal also never reached "step one" in the approval procedure of modern normative stratigraphy.

In conclusion, the task of subdividing the Pleistocene into practical, historically sound, widely recognisable units, with officially defined bases, lies all in front of us and must be tackle vigorously by the new SQS.

\section{Suggestions on the future objectives, work programme and membership of SQS}

\section{Objectives}

In our opinion, the objectives of SQS in the next few years should be deliberately very pragmatic and mainly focused on:

a) the agreement on an official chronostratigraphic/geochronologic framework for the entire Pleistocene Series/Epoch, and

b) the subsequent selection, approval and ratification of all relevant boundary stratotypes (GSSPs).

The multidisciplinary stratigraphic scale of the Quaternary is well established (Berggren et al., 1995a, b), including microplankton stratigraphy, magnetostratigraphy, stable isotope stratigraphy, all of them intercalibrated and framed into the new astronomic time scale 
(Shackleton et al., 1990; Hilgen, 1991; Lourens et al., 1996). This will certainly facilitate the understanding of the position in time of different chronostratigraphic units proposed in the past, thus rendering SQS's task a little easier.

Only after having established the standard chronostratigraphic scale for the entire Quaternary, a switch in the purposes and focus of SQS will be possible, for example embracing the task of developing a standard nomenclature for other kind of stratigraphic units (continental chronostratigraphic units; climatostratigraphic units; glaciostratigraphic units, etc.).

\section{Work Programme}

The first, and most difficult issue, is the agreement on a suite of chronostratigraphic units to represent and typify the whole Pleistocene. How to do so could be the subject of the first consultations among the newly appointed members of SQS.

For certain, we already have a number of exhaustive documents (e.g. Vai, 1996) and of informal schemes (Rio et al., 1991; Cita and Castradori, 1995) that depict different chronostratigraphic approaches with their pros and cons, strengths and weaknesses.

Of course, also the most important standard chronostratigraphic scale (e.g. Berggren et al., 1985; Berggren et al., 1995a, b; Harland et al., 1990) are a useful source of reference and information, even if the subdivision of the Pleistocene has often been elegantly bypassed in those compilations.

Therefore, in our opinion, the time is now for a final decision to be taken and for an official scheme to be finally adopted, without producing any major efforts from the analytical point of view.

What SQS needs is a comprehensive document that details, as impartially as possible, the existing situation. This document could then be circulated among all SQS members. A questionnaire might then follow to gather the opinion of everybody in view of the formulation of a proposal for voting.

In doing so, the primary event(s) that should guide our search for a boundary stratotype will also be discussed and approved.

At this point, one will have the possibility of either submitting the chronostratigraphic scheme and the guide events to ICS for approval, prior to the actual proposal of the related GSSPs, or continue with the selection of GSSPs and then submit scheme, events and GSSPs all together. Whether to prefer one option or the other will also be, of course, a matter of discussion within SQS.

A "natural" dead-line for this process would be the next IGC (Florence, summer 2004).

We feel convinced that by that date, the agreement on the standard chronostratigraphic scheme and the related guide-event could be reached. The question whether or not there will also be the relevant GSSPs approved, remains doubtful.

However, the deadline of year 2008 (official date set by ICS to complete all GSSPs) can be met without any doubt.

\section{Membership}

We suggest to include in the membership of the new SQS a significant number of scientists with expertise in the fields of stratigraphy of marine sediments in general, micropaleontology of the oceans in general, integrated stratigraphy of the Italian Quaternary type-sections and of sections from other prominent areas for the marine Quaternary (Japan, New Zealand).

\section{Concluding remarks}

Provided that the new SQS is composed of scientists representing the full range of disciplines dealing with Quaternary sediments and time, we are confident that the completion of the Standard Chronostratigraphic Scale for that System will be easily accomplished before 2008.

In doing so, the standard procedures of modern normative stratigraphy adopted by ICS should, and can easily be, respected and fully implemented.

The Italian stratigraphic community, as represented by the Italian Commission on Stratigraphy, looks forward to a fruitful collaboration on these issues.

\section{References}

Aguirre, E., and Pasini, G., 1985, The Pliocene-Pleistocene Boundary. Episodes, v. 8, no. 2, pp. 116-120.

Bassett, M., 1985, Towards a "Common language" in stratigraphy. Episodes, v. 8 , pp. $87-92$.

Berggren, W. A., Hilgen, F. J., Langereis, C. G., Kent, D. V., Obradovich, J. D., Raffi, I., Raymo, M. E., and Shackleton, N. J., 1995a, Late Neogene (Pliocene-Pleistocene) Chronology: New Perspectives in High Resolution Stratigraphy. Geol. Soc. Am. Bull., v. 107, pp. 1272-1287.

Berggren, W. A., Kent, D. V., Swisher III, C. C., and Aubry, M.-P., 1995b, A Revised Cenozoic Geochronology and Chronostratigraphy. In: Berggren, W.A., Kent, D.V. and Hardenbol, J. (eds.), Geochronology, Time Scales and Global Stratigraphic Correlations: A Unified Temporal Framework for an Historical Geology. SEPM Spec. Vol. 54.

Cita, M. B., and Castradori, D., 1995, Workshop on marine sections from the Gulf of Taranto (southern Italy) usable as potential stratotypes for the GSSP of the lower, middle and upper Pleistocene (Bari, Italy, Sept. 29Oct. 4, 1994). Il Quaternario, v. 7, no. 2, pp. 677-692.

Doderlein, P., 1872, Note illustrative della carta geologica del Modenese e del Reggiano, Memoria III, 74 pp.

Gignoux, M., 1913, Les formations marines pliocènes et quaternaires de l'Italie du Sud et de la Sicile. Ann. Univ. Lyon, N.S., v. 1, no. 36, pp. 24693.

Hedberg, H. D. ed., 1976, International Stratigraphic Guide - A guide to stratigraphic classification, terminology and procedure. John Wiley and Sons, New York, 200 pp.

Hilgen, F. J., 1991, Astronomical calibration of Gauss to Matuyama sapropels in the Mediterranean and implication for the Geomagnetic Polarity Time Scale. Earth and Planet. Sci. Lett., v. 104, pp. 226-244.

Lourens, L. J., Antonarakou, A., Hilgen, F. J., Van Hoof, A. A. M., Vergnaud-Grazzini, C. and Zachariasse, W. J., 1996, Evaluation of the Plio-Pleistocene astronomical timescale. Paleoceanography, v. 11, no. 4, pp. 391-413.

Remane, J., Bassett, M. G., Cowie, J. W., Gohrbandt, K. H., Lane, H. R., Michelsen, O. and Naiwen, W., 1996, Revised guidelines for the establishment of global chronostratigraphic standards by the International Commission on Stratigraphy (ICS). Episodes, v. 19, no. 3, pp. 77-81.

Richmond, G. M., 1996, The INQUA-approved provisional Lower/Middle Pleistocene boundary. in Turner ed., The early Middle Pleistocene in Europe, pp. 319-327, Balkema (Rotterdam).

Rio, D., Sprovieri, R., and Thunell, R., 1991, Pliocene-lower Pleistocene chronostratigraphy: A re-evaluation of Mediterranean type sections. Geol. Soc. Am. Bull., v. 103, pp. 1049-1058.

Rio, D., Castradori, D., and Van Couvering, J. A., 1998. Against the lowering of the Pliocene-Pleistocene boundary. Neog. Newsl., v. 5, pp. 78-103 (available on the web at www.geo.uu.nl/SNS/).

Salvador, A. ed., 1994, International stratigraphic guide: a guide to stratigraphic classification, terminology, and procedure, second edition: Boulder: Geological Society of America, and Trondhjeim, International Union of Geological Sciences, xix +214 pp.

Shackleton, N. J., Berger, A., and Peltier, W. R., 1990, An alternative astronomical calibration of the lower Pleistocene timescale based on ODP Site 677. Trans. Royal Soc. Edinburgh: Earth Scien., v. 81, pp. 251-261.

Vai, G. B., 1996, Revisione critico-storica dei piani marini del Quaternario. Servizio Geologico d'Italia, Miscellanea VI..

Vai, G. B., 1997, Twisting or stable Quaternary boundary? A perspective on the glacial Late Pliocene concepts. Quaternary Internat., v. 40, pp. 11-22.

Van Couvering, J. A., 1996, The new Pleistocene. in J. A. Van Couvering ed., The Pleistocene boundary and the beginning of the Quaternary. Cambridge Univ. Press, pp. 1-6. 